\title{
Less Than One But More Than Many \\ Anthropocene as Science Fiction and Scholarship-in-the-Making
}

\author{
Heather Anne Swanson, Nils Bubandt, and Anna Tsing
}

ABSTRACT: How might one responsibly review a field just coming into being-such as that provoked by the term Anthropocene? In this article, we argue for two strategies. First, working from the premise that the Anthropocene field is best understood within its emergence, we review conferences rather than publications. In conference performances, we glimpse the themes and tensions of a field-to-come. Second, we interpret Anthropocene as a science-fiction concept, that is, one that pulls us out of familiar space and time to view our predicaments differently. This allows us to explore emergent figurations, genres, and practices for the transdisciplinary study of real and imagined worlds framed by human disturbance. In the interplay and variation across modes for constructing this field, Anthropocene scholarship finds its shape.

KEYWORDS: conference review, co-species relations, environmental studies, field-building, genre, philosophies of nature, structures of feeling, transdisciplinarity

\section{Introduction}

[T] he more shoe shops there were, the more shoes they had to make and the worse and more unwearable they became. And the worse they were to wear, the more people had to buy to keep themselves shod, and the more the shops proliferated until the whole economy of the place passed what I believe is termed the Shoe Event Horizon, and it became no longer economically possible to build anything other than shoe shops. Result-collapse, ruin and famine. Most of the population died out. Those few who had the right kind of genetic instability mutated into birds-you've seen one of them-who cursed their feet, cursed the ground, and vowed that none should walk on it again. (Douglas Adams, describing the ruin of planet Frogstar World B in Restaurant at the End of the Universe [(1980) 2009]: 59).

The Anthropocene is that proposed geological epoch in which human activity has become a force of nature that radically and irrevocably alters the earth we inhabit. ${ }^{1}$ The term asks us to take the view from afar and look at the earth as if we were explorers from the far distant future. From this future and even without any humans left, we would still see a set of geological strata unified by massive human disturbance (Zalasiewicz 2009). In this sense, Anthropocene is a science-fiction concept, that is, a concept that pulls us out of familiar space and time to view our predicaments as if they belonged to a distant land.

Viewing the Anthropocene as science fiction is useful in building a review of the field of scholarship that the term is currently bringing into being. Science fiction, Ursula Le Guin (1969) once remarked, is not a prediction about the future as much as it is a thought-experiment about 
the present. The emerging field of Anthropocene studies is a series of such thought experiments. The Anthropocene not only marks a geologic time, but also a scholarly one-a moment when a particular term has captivated scholarly imaginations. The term carries high hopes, not only for long-overdue attention to global environmental problems, but also for a much-longed-for break in the wall that has separated the human and natural sciences (Snow 1961). The enthusiasm for the term Anthropocene (and a good part of the suspicion against it) is its apparent promise to mark a "paradigm shift" in Thomas Kuhn's (1996) sense, in which the distinction between "nature" and "culture" will collapse along with the academic divisions that upheld it. It is too early to tell whether these promises will be fulfilled. For while the literature on the Anthropocene is growing rapidly across and between a diverse range of disciplines, the study of the Anthropocene is still a field in search of itself.

This has consequences for what it is possible to say about Anthropocene scholarship. The field is so new that to focus on its publications at the current moment would be insufficient. The first run of Anthropocene scholarship has hit the newsstands, one might say, but this early literature does not adequately capture the emerging field. Instead, a respectful reviewer needs creative ways to touch its promises and dilemmas. Our challenge is therefore how to map a science-to-come. Conferences are a place to begin such a mapping exercise.

In the past few years, conferences with "Anthropocene" in the title have increased even faster than CO2 levels. Nearly every major meeting within the social sciences and humanities has had multiple Anthropocene-related panels. ${ }^{2}$ We have chosen five conferences that reflect the potential and challenges of Anthropocene scholarship. We are not, however, ethnographers of these conferences, and we do not in this article propose to "take readers there" (Little 1995; MacDonald 2010; Poncelot 1990). Rather, based on semi-structured interviews with organizers and participants, and document analysis of conference programs, position papers, suggested reading lists, and conference websites, we propose reading conferences as a review of literature-to-come. Our object is the field-in-the-making, not the conference-in-the-making.

Conferences are more than papers-in-progress. They are varied and often creative gatherings, full of diverse voices and arguments. As such, they lay out possible new trends and articulate connections across research areas. They are venues for the emergence of academic "structures of feeling." Raymond Williams provides our methods when he calls for "modes of analysis which, instead of reducing works to finished products, and activities to fixed positions, are capable of discerning, in good faith, the finite but significant openness of many actual initiatives and contributions" (Williams 1977: 114). According to Williams, "structures of feeling can be defined as social experiences in solution, as distinct from other social semantic formations which have been precipitated and are more evidently and more immediately available" (Ibid.: 133-134). At conferences, ideas come in fluid form. They may end up evaporating, or they may collect in rivulets that come to water publications, institutions, and schools further downstream. We argue that a review of conferences can better access this field in formation than an assessment of existing publications. By watching scholarship emerge in conferences, we review a field that does not yet formally exist.

The inchoateness of Anthropocene scholarship is our point of departure and is at the heart of our argument. It allows us to address a crucial interdisciplinary question: Is there only one Anthropocene, or are there many Anthropocenes? The Anthropocene, we argue, is still "less than one but more than many." This slogan takes off from a discussion in anthropology about phenomena that are "more than one and less than many" (Strathern 1991: 35). Anthropologists show that many ordinary phenomena fracture when one examines the multiplicity of practices through which they are made. For example, Annemarie Mol demonstrates that atherosclerosis is both a disease for doctors and an experience for patients; in this multiplicity, it is "more than 
one and less than many" (2002). Anthropocene scholarship has this both-and quality, but without any of its concreteness. It belongs to a comparable but contrasting set of phenomena: those without enough materialization to constitute a one and still too amorphous to be numerable at all. The inchoateness of Anthropocene scholarship attests to our current inability to capture the reality of the Anthropocene. Both the Anthropocene and the scholarship that tries to grasp it are less than one and more than many.

Inchoateness, however, does not mean formlessness. Our "less than one but more than many" insight encourages us to look carefully at will-o-the-wisp structures of feeling as they emerge in Anthropocene discussions. Thus, we characterize partial and incomplete figurations of the field both in their effervescence and through diagram-like simplifications that offer some of their ethos. Our characterizations are in the spirit of science fiction. The five conferences on which we focus are:

1. The Anthropocene Project Opening Event, held in Berlin in January 2013.

2. Anthropocene Feminism, held in Milwaukee in April 2014.

3. The Thousand Names of Gaia, held in Rio de Janeiro in September 2014.

4. The Changing Nature of Nature, held in Kyoto in December 2009.

5. Anthropocene: Arts of Living on a Damaged Planet, held in Santa Cruz in May 2014.

These five conferences each propose an alternative characterization of the Anthropocene, highlighting, respectively, its call for transdisciplinary scholarship, its dilemmas of contamination in both politics and science, its evocation of contrasts between Western science and indigenous voices, its directive to attend to devastating human destruction, and its potential to show us new ways of being human in a multispecies world. These we call the "figurations" of each conference. Figurations are organizers' ways of imagining a field. They point to central dilemmas that could construct Anthropocene fields. Each conference also embodied a certain ethos or "genre." If figurations were the dreams of the conferences, the genres were their processes. Genres make dreams possible, while assembling participants around a certain way of working. They allow us to interpret new efforts within older legacies. Creative experimentation with genre often opens imaginations. The science-fiction conceit inspires us to explore each conference through its figurations and genres-but also its practices. Practices get the work done, turning imaginaries into concrete acts of worlding.

The differences in the five conferences and their contributions to Anthropocene scholarship are as instructive as their commonalities. The differences were linked to location in the broadest sense of the term: they were located in diverse geographical places, disciplinary contexts, institutional settings, and networks of financial support in ways that mattered. Within different configurations of funding, organizer backgrounds, disciplinary configurations, and political stakes, the Anthropocene takes on very different forms.

Location also matters to our reading of these conferences. Reviewers, like all scholars, offer "situated knowledge" (Haraway 1988). The authors of this article are anthropologists, and we review the emerging field of Anthropocene scholarship from our training and experience. We are also members of a particular team of Anthropocene scholars: Aarhus University Research on the Anthropocene (AURA). In our ongoing work, we cannot but compare other articulations of the field with that we are developing. We orchestrated our own Anthropocene conference in May 2014, as a part of our five-year project on the same theme. ${ }^{3}$ As we did so, other conferences proved good with which to think. Our version-like those we review-is molten. We are shaped by other exercises just as we hope to influence them. In this context, we offer not a sparring match but rather a curious walk through a landscape of fluidic field-building. 


\section{Berlin: Dancing at the End of the World}

Quick guide: figuration-transdisciplinarity; conference genre-carnival; practices—networking

Somtow Sukaritkul's (1986) classic sci-fi story, "Fiddling for Water Buffaloes," asks readers to navigate artful confusions across a number of categories, building from "traditional" and "modern" through "spirit," "alien" (extraterrestrial), and "foreigner." During a live-dubbed showing of "Star Wars" in a rural Thai theater, a spaceship arrives, and an alien who resembles a cockroach possesses the dubber who is the narrator's brother. Luckily, his grandmother calls in a Buddhist spirit exorcist, who (without recognizing the extraterrestrial situation) achieves a meditative state, which allows the alien to transfer into the American archaeologist who has just dug up the alien transponder among other ancient ruins. In this madcap frolic through the categories of our times, readers are pushed beyond familiar boundaries. In the ambitious Anthropocene event held in Berlin, these boundaries are not those separating spirits from aliens but art from science. As for Somtow, however, the pleasures of transgression and display provide the incentive.

"The Anthropocene Project" is an initiative of the Haus der Kulturen der Welt (HKW) in cooperation with the Max Planck Society, the Deutsches Museum, the Rachel Carson Center for Environment and Society, Munich, and the Institute for Advanced Sustainability Studies, Potsdam. ${ }^{4} \mathrm{HKW}$ is a Berlin-based experimental center for "international contemporary arts and a forum for current developments and discourse." As Bernd M. Scherer, the organization's director, explains:

The Haus der Kulturen der Welt is not a research institution in the academic sense, neither are we artists-what we do is basically the following: we work with aesthetical strategies to perform knowledge ... I just want to give a few points, a few aspects in which this curatorial way of working consists. ... The first one is creating a certain kind of aesthetical space wherein knowledge is performed. The second one is to create certain kinds of constellations between important actors, producers of knowledge. And the third one is to develop certain formats where knowledge is performed also in an aesthetical way, for example speaking through the object. (Haus der Kulturen der Welt 2013a: 2)

In 2011, the Anthropocene came to HKW's staff as an intriguing term that highlighted the blurring of nature-culture boundaries and called out for new "cultural narratives." Christian Schwägerl, a science journalist and author of a book about the Anthropocene (2014), Reinhold Leinfelder, a geologist, paleontologist, and former head of the Berlin Natural History Museum, and Scherer, HKW's director, put together the proposal for the Anthropocene project, together with assistants with backgrounds in history of science, cultural studies, media studies, and art history. Although the HKW Anthropocene Project has spanned two years and encompassed several workshops, exhibits, and a curriculum project, we focus here on the project's 2013 opening event.

The "Opening Event" was precisely that-an event. It took the genre of the academic conference and crossed it with that of the art installation. The event's central "performers" were primarily academics, including climate scientist Will Steffen, historian Dipesh Chakrabarty, geologist Jan Zalasiewicz, geographer Erle Ellis, anthropologists Elizabeth Povinelli and Michael Taussig, and science and technology-studies scholar John Law. But its form exploded disciplinary conventions. In addition to reports from climate scientists, the carnivalesque event featured a dancer who asked "how to dance the Anthropocene" in order to create sensations that were very different from those of listening to a lecture or reading a journal article. A "metabolic kitchen" served Anthropocene snacks, such as pizza on a stick and corned beef hash in a jar. In a comment on the way in which the organic and the industrial are entangled in the food process- 
ing systems of the Anthropocene, the dishes were cooked on-site from the cuts of a whole cow in glass-caged kitchens that progressively used all parts of the cow's body during the conference. "It's not theater," one of the coordinators explained of the HWK Anthropocene project, "but it has a theatrical element." One participant referred to the event as "an academic rock concert."

The Anthropocene, as performed in Berlin, stressed the human permeation of global processes and the rise of "man-made nature." The focus, however, was less on environmental destruction, per se, than it was about the end of binary categories and of the concept of nature as such. One of the statements in the opening event program captures this sentiment: "We are no longer human. It is no longer nature. Both have come and gone, a thing of the past. What comes after? The question may be asked differently: what came before that allows for an after?" (Haus der Kulturen der Welt 2013b: 16-17). Because it ushers in the "end" of Western metaphysics, the Anthropocene is, in the HKW context, an exciting time-a time that calls out for new knowledge practices that eschew Cartesian divisions. The Anthropocene is thus as much an "opportunity" as it was a tragedy to bemoan.

The HKW group found important inspiration in natural philosophy, which sought to bring together empirical research and speculative inquiry into a single scholarly practice. Some members tentatively described the project's efforts as an attempt to create a "new natural philosophy." This allowed them to seize the chance to challenge "modern" disciplinary configurations, particularly the split between the natural sciences on one hand and the arts and humanities on the other. Through novel forms of staging and performance, they hoped to spark creativity, imagination, playfulness, and experimentation - and, hopefully, a new metaphysics. Because HKW is a museum rather than a research institution, the staff saw their task as guiding form more than programming content. The medium of arts-based transdisciplinary encounter was the message. Without a rigid agenda, HKW was able to welcome everyone working on the Anthropocene to the party, regardless of their theoretical commitments. This is what we mean by carnival.

HKW also explicitly encouraged the "transplanting" of methods, concepts and styles from one discipline to another. For example, they urged participants to take natural science terms and do radically unorthodox things with them. But although the goal was to encourage people to engage new conversational partners, the result was, at times, more similar to what development psychologists call "parallel play" than to what they call "cooperative play." Although the HKW project "got everyone into the same room," sometimes they actually talked together and sometimes they did not. Will Steffen's keynote lecture for instance delivered a convincing argument for his "Great Acceleration thesis." The Anthropocene can be dated to the Industrial Revolution and should be defined, he argued, by the acceleration of species extinctions, carbon emissions, and rising global mean temperatures associated with post-World War II production growths (Steffen et al. 2011). Steffen's lecture, one of the conference highlights, illustrated the double tonality of opportunity and doom that seemed to inform the conference: a global shift was currently happening, urgent action was needed, and all disciplines-including the human and social sciences-were called upon to understand the predicaments of our present and reorient our future. However, this moment of apocalypticism, mixed with intimations of transdisciplinary salvation, was marked by little discussion of the scientific epistemology that informed this temporality. Everyone agreed that cooperative play was required in the Anthropocene, but the epistemic ground rules of this transdisciplinary game of scholarly understanding were harder to agree upon.

Several members of the AURA team attended the HKW event, and they were variously confused and entertained by the grand spectacle of it. Sometimes the juxtapositions were overwhelming. A biologist attending Michael Taussig's dramatic reading of a poem in honor of the sun was honest about his disorientation: "Is anthropology always like this?" In its exhilaration and confusion, HKW's conference offered a generous beginning for Anthropocene discussions. 
But is the Anthropocene merely a carnival? The celebratory aesthetic left some participants worried about theory and politics. The Milwaukee conference addressed this fear.

\title{
Milwaukee: Polluted Lives
}

Quick guide: figuration—contamination; conference genre-the everyday uncanny; practicede(con)struction

\begin{abstract}
“The Last Flight of Dr. Ain," first published in 1969, is perhaps James Tiptree, Jr's most satisfyingly feminist story-despite the fact that no women appear in it. Throughout her work, Tiptree forces readers to rethink their assessments of love as pulpy salvation, but here, in a most subversive way, love is salvation, even as genocide. Dr. Ain is a government scientist, but he has gone rogue. For the love of the earth, he engineers a virus, carried by birds, that will wipe out the human race but leave the rest of earth's ecologies untouched. As he travels to an international conference to announce his act, he stops in Iceland to feed the migratory birds, ensuring that the virus will spread across the planet. "Yes, of course it is very wrong," he tells the conference, "I told you that. We are all wrong. Now it's over." (Tiptree 2004: 6)
\end{abstract}

Like the HKW project, the Anthropocene Feminisms conference, organized by the Center for 21st Century Studies (C21) and held at the University of Wisconsin, Milwaukee, in April 2014, brought art to bear on more traditional academic forms as a way of engaging the Anthropocene. ${ }^{5}$ Yet its approaches and aesthetics were markedly different. In contrast to the HWK's theatrical performances in a European metropolitan center, the Anthropocene Feminisms conference cultivated a self-described "DIY, queer, vegan" aesthetic in a small Midwestern American city. This project was also explicitly feminist in form with an open call for papers and many panels featuring graduate student scholars.

The C21 organizers-three English professors and one philosopher-were troubled by some of the Anthropocene conversations that they saw emerging, and they sought to intervene in two ways. First, they were irked that some Anthropocene projects depicted the blurring of the nature-culture divide as novel. Talking back to Anthropocene events that painted this "new era" as one of uncharted intellectual territory, they invoked feminist precedents. In the words of one organizer, they wanted their event to say, "Wait a second, the kinds of conversations that are happening around the Anthropocene-be they about nature/culture, difference and inequality, critiques of capitalism, et cetera, are not new. Feminist scholars have been talking about many of these things for a long time."

Second, the C21 group rejected framing the Anthropocene as a carnivalesque "celebration of opportunity and possibility," in which boundary transgressions offered a (masculine) pleasure of "freedom" from past constraints. Instead, in Milwaukee, transgression was the stuff of contamination, pollution, and toxicity. In the words of the C21 organizers, the Anthropocene was "a moment of uncertainty and trouble," characterized by a pervading sense that everything is not going to be okay. Inspired by the work of Donna Haraway, they insisted that boundary crossings were as likely to be disastrous as emancipatory. As the "Anthropocene Feminism" call for papers puts it:

[T] he Anthropocene is a strikingly resonant iteration of the problematic forcefully articulated in Donna Haraway's "Cyborg Manifesto," which sees the human, nonhuman, culture, and nature as inextricably entangled, and warns that the consequences of attempts to dominate human and nonhuman nature can be at once devastatingly successful and productively perverse. ${ }^{6}$ 
The C21 organizers felt Haraway's ambiguous and compromised cyborg expressed the politics of their event: How do we "stay with the trouble"-alert to the webs of power and complicity in which everyone is entangled (Haraway 2010)?

The C21 organizers did not hesitate to present a darker Anthropocene future than that of HKW's event in Berlin. As one of their conference motifs, they selected an animation by Marina Zurkow titled "Slurb," a word that blends "slum" and "suburb." With echoes of post-Hurricane Katrina New Orleans, the animation depicts a flooded world in which jellyfish bloom and garbage piles dominate. ${ }^{7}$ It invokes a future to come and a present that already is-a kind of science-fiction realism. Scrolling along at an even pace and paired with a mash-up soundtrack combining electronic sounds and human voices, the video portrays a world where, in the midst of real disaster, life continues. While there are fleeting moments of beauty, the life that continues here is clearly impoverished, without diversity and with a color palette pared down to a few shades of red and blue. It is a deeply polluted world with no beginning, end, or way out. No hope for a revolution, scientific or political, sits on the horizon.

As in the James Tiptree, Jr., short story, contamination at the Milwaukee event always took a double form: it simultaneously invoked environmental pollution and compromised positions. But the C21 conference was focused on the politics of the everyday, rather than on singular, world-changing acts, as in the Tiptree story. In one of the keynote addresses, for example, science studies scholar Myra Hird troubled ordinary practices of waste disposal. Although many middle-class Euro-Americans see recycling as a fulfillment of environmental responsibilities, Hird explained how recycling does nothing to address real waste disposal problems. On the contrary, recycling both fails to work technically and impairs our ability to address waste by creating subjects who think they have resolved pollution by tossing a few bottles into a bin. Describing an Inuit town where people leave their trash strewn about, Hird turns garbage narratives on their head. The Inuit, she argues, are not "polluters" or "bad environmentalists." Instead, the Inuit refusal to hide trash is a mode of resistance. By leaving plastic materials out as they would a seal carcass, the Inuit community shows how the products on which we all have come to depend do not break down. Unlike Euro-American recycling practices that cover over dirty truths about trash, the Inuit community allows it to remain on the surface, refusing to make waste and wasted landscapes disappear. No one, Hird argued, be they Inuit or recycler, is "right" or pure.

For one organizer, the defining moment of the conference was watching the attendees decide what to do with the remains of their lunches after they listened to Hird's talk. They posed anxiously in front of trash and recycle bins, no longer satisfied with tossing their waste into the recycle container and disturbed by the lack of a "good" option. The scene captured the conference's feminist approach to theory. Troubled by practical questions of how to get through the day, they wanted Anthropocene questions to bubble up from everyday life, rather than descend from philosophical discussions of nature/culture binaries. The garbage symbolized their feminist commitment to situated knowledges and politics: despite Anthropocene scholars' tendency toward "globality" and "universality," they insisted that the task of Anthropocene scholarship lay in doing both theory and politics from that particular garbage can, located in that particular conference venue. The damned-if-you-do-damned-if-you-don't dilemma posed by the garbage cans-and yet the inescapable requirement to act-encapsulated the complexities of Anthropocene politics that were irreducible to personal "choice." Pleasure and possibility were not absent from the Milwaukee event, but they lay in the delights of deconstruction and the analysis of the ongoing contradictions of capitalism, consumer society, and environmental politics, rather than in any imagined escape from them. 


\section{Rio: Challenging Ontologies}

Quick guide: figuration-indigenous voice; conference genre-multiple perspectives; practicephilosophy-fiction

In Arthur C. Clarke's 1953 short story “The Nine Billion Names of God," a Tibetan monastery employs a computer and its American operators to compile the names of God, a project on which they have been working for some three centuries. Once the names are compiled, they believe, God's purpose will be achieved and the world will come to an end. The computer operators, nervous that the monks will attack them if the world does not end, contrive to have the computer finish just in time for their flight home. As they walk through the night to the landing strip where the plane awaits, the stars begin to go out. (Clarke 2000)

"The Thousand Names of Gaia: From the Anthropocene to the Age of the Earth" colloquium in Rio de Janeiro held out a third vision of the Anthropocene, one attuned to the specificity of modern modes of existence and the need for alternatives. In a tightly packed program lasting five days in mid-September 2014, the conference featured presentations and panel discussions, in three major languages (Portuguese, French, and English), all available in simultaneous translation. Acutely aware of being located in Brazil, a booming BRIC country with a diverse but disenfranchised indigenous population and a tropical forest biotope at risk, the colloquium hosted scholars from abroad (including Isabelle Stengers, Bruno Latour, Alf Hornborg, Bronislaw Szerszynski, Vinciane Despret, Patrice Maniglier, and Lesley Green), but was critically carried by a strong representation of important Latin-American academics, including conference co-organizers Déborah Danowski and Eduardo Viveiros de Castro as well as Marcos Matos and Mauro Almeida. Equally significant was the presence of several Brazilian activists (José Augusto Pádua and Marcio Santili) and indigenous leaders, such as Silvia Rivera Cusicanqui and Ailton Krenak. A few participants came from the natural sciences, but the cross-disciplinary goal of the colloquium was more restricted: "to promote a discussion of a predominantly anthropological and philosophical character about the perspectives of an inextricably 'natural' and 'cultural', environmental and civilisational crisis" (Danowski et al. 2014: 2).

The Rio colloquium grew out of a critical engagement with, and a worry about, the Anthropocene, both as a concept and as a vision of scientific and political practice. Inspired by the "ontological turn" (for example, Viveiros de Castro et al. 2014), the Rio colloquium called for reflections on what kinds of humans and perspectives were excluded from the Anthropocene. The colloquium was convened to explore the suspicion that the Anthropocene, in spite of its alleged break with the nature-culture divide, is still the expression of a scientific Western cosmology. In this cosmology there is just one kind of humankind and one kind of nature, made in their difference from each other. It was political and theoretical opposition to this idea of a "one-world world" (Law 2011) in much Anthropocene scholarship that motivated the Rio colloquium. As a consequence, the organizers were alert to the possibilities of incorporating the voices, perspectives and life worlds of Amerindian peoples to challenge hegemonic academic theories of the Anthropocene. The position paper expressed the importance of multiple perspectives:

It is high time to make room for the perspective of others, of other "we", of those humans who live in worlds in which "human" and "world" are distributed in radically different ways. In short, it now becomes essential to find out whether "we ourselves" are really capable of recognising the absolute legitimacy of the presence of these other "we's", i.e., the indigenous peoples, in a discussion about the fate of a common planet. (Danowski et al. 2014: 4-5) 
The Rio colloquium was an attempt to mobilize this discussion. Of the conferences we have reviewed, the role of ideas was perhaps most central in Rio. Philosophy was seen as the practice through which other modes of being could be expressed. Bruno Latour's reflections on Gaia were an important figure for this ambition. Gaia, as Latour had earlier phrased it, pushes us into "philosophy-fiction" (2014). Latour's opening keynote lecture offered a critical engagement with a recent book on Gaia by British biologist Toby Tyrrell (2013). Tyrell's book trashes the Gaia hypothesis of chemist James Lovelock and microbiologist Lynn Margulis, which names the earth as a symbiotic being of interdependent organisms. In response to Tyrell's scientific muffling, Latour began an almost Buddhist-like chanting of the names of Gaia, good and bad. Latour named them, but they were not of his making. Rather, they were encodings of the strange and ridiculous precepts of Tyrell and other scientist naysayers: "Gaia-Global State of Control," "Gaia-Air Conditioning System," "Gaia-Providence-State." During his talk, Latour tallied some 35 names. If Tyrrell was like the disbelieving computer scientists in Arthur C. Clarke's short story, Latour and the conference organizers were akin to the Tibetan Buddhists who chanted names for the end of the world. At the heart of the colloquium's agenda was a widening of the separation between Gaia and the Anthropocene. ${ }^{8}$ As the organizers explained in their position paper, the Anthropocene requires a temporal logic, "in which the chronological scales of human history, on the one hand, and evolutionary biology and geophysics, on the other, have come dramatically closer to each other, if not changed positions altogether" (Danowski et al. 2014: 1). Gaia, in contrast, "would name a new way of imagining and occupying space.... Gaia is thus a call for us to resist the Anthropocene, to learn to live with it but against it, that is, against ourselves. The enemy, in short, is 'us'- 'we' Humans" (Danowski et al. 2014: 1, 4).

In order to resist this universal, modern "we," the colloquium organizers proposed a different "we," a consciously Brazilian "we" that was attentive to the existence of multiple indigenous "we's." The colloquium intentionally included representatives from Brazilian environmental NGOs and indigenous organizations in an attempt to give voice to this more differentiated "we." Yet some participants felt that indigenous and activist voices remained marginal to the event. Environmental activists argued that political action ought to trump ontological reflection, while indigenous representatives seemed to feel ventriloquized by the discourse of Amerindian perspectivism. The Rio colloquium in that sense became the unintended site of contestation between what Gayatri Spivak has called the two modes of subaltern representation: "representation as 'speaking-for', as in politics, and representation as 're-presentation,' as in arts and philosophy" (Spivak 1988: 275). While the issue of whether indigenous leaders or anthropologists best articulated the indigenous voice could not be solved, Isabelle Stengers in her concluding remarks made a passionate plea for the possibility of uniting cosmological and political projects in the articulation of alternatives to hegemonic Western knowledge practices. Stenger's remarks pinpointed the predicaments of including multiple perspectives that confront, or should confront, all Anthropocene scholarship. For in the Anthropocene, the inclusion of indigenous and subaltern voices is more important, but also more fraught, than ever.

If in Rio, cosmological "philosophy-fiction" sought to obviate the Western opposition between nature and culture, in Kyoto it was empiricism that did just that work. Fieldwork there followed a Japanese tradition of non-Enlightenment observation, a legacy of "no nature no culture." Indeed, the contrast could not be any starker than that between the project in Rio, which was all about naming, refusing observation, and the project in Kyoto, which set about observing, but which, in the tumbles of translation, refused to say its name. It is instructive that, at their most promising, the two projects found considerable common ground. 


\section{Kyoto: Big Science, Otherwise}

Quick guide: figuration-disturbance, human and otherwise; genre-description; practiceexcursion

In Nguyen Huy Thiep's "Salt of the Jungle" (1996), Mr. Diem goes hunting to try out the new double-barreled shotgun his son has just sent him from abroad. Yet the jungle is more animated than he expects. The monkeys he shoots show loyalty, grief, and anger; it is hard to treat them just as targets. Perhaps, he thinks, they are ghosts or spirits. Pursuing the monkeys within a series of mishaps, he begins to lose his clothes and his possessions. His lunch infuses into a termite mound; a baby monkey tumbles with his rifle over a cliff. Mr. Diem's mood shifts rapidly between annoyance, compassion, confusion, and unexpected awareness. Finally, he ambles naked and without provisions. He finds himself in a mass of salty flowers, the unpredictable gift of the forest.

Let us now turn to Japan, where in 2009, a group of scholars at Kyoto University organized a conference titled "Changing Nature of Nature: New Perspectives from Transdisciplinary Field Science." Working in a historical moment prior to the "Anthropocene" boom, the Kyoto conference did not invoke this term at all. Yet, in its practices-a focus on interdisciplinary exchange, a refusal of nature-culture divides, and an attempt to address the urgency of global environmental problems-it invites comparison with Anthropocene scholarship.

The Kyoto conference, coordinated by anthropologist Noboru Ishikawa, was part of a fiveyear project entitled In Search of Sustainable Humanosphere in Asia and Africa. "Humanosphere" has many of the same dreams and flaws as Anthropocene; it points to a world in which humans have become a force of nature. This Humanosphere project was funded as "big science," and project documents offer a rather conventional picture of interdisciplinarity, where scholars from different fields would gather around a common theme, but continue their own work, as usual. Indeed, from those documents alone, no one would suspect that the conference would sponsor a subtle, yet transformative conversation between the natural and social sciences. These conversations negotiated the relation between Japan and "science," and they made something important possible.

From where did this uncommon magic arise? As participants in this conference, Swanson and Tsing sensed a ghostly presence animating the event. Something original, but almost entirely untheorized, happened because of its silent presence. The ghost was Kinji Imanishi (1902-1992), a pioneering biologist and anthropologist. Imanishi's legacy was felt before conference presentations even began. The event began not in a lecture hall, but in the field, with an exercise in transdisciplinary observation. Conference participants visited a rural area to observe village-based water and forest management, as these remade the landscape. This exercise was very much in the spirit of Imanishi's teaching practice. The point was to be stimulated by the encounter with the world, in all its surprises. While no one discussed Imanishi's legacy at the conference, it made something important happen: natural scientists and humanists were talking together about places of shared interest in substantial ways. The field trip was followed by presentations from field biologists, ecologists, historians, political scientists, and ethnographers. By foregrounding observation and more-than-human sociality in disturbed landscapes, the conference participants were able to work across divides between humans and nonhumans.

Imanishi's scholarship, which crossed what now are considered natural and social sciences, did similar work itself (for example, Imanishi 2002). He is best remembered in the field of primatology, where he pioneered methods for knowing monkeys not as interchangeable research objects but as social individuals. Imanishi's monkeys had names and histories. Like the hunter in 
Nguyen Van Thiep's story, Imanishi was unable to treat them as simple "targets" of knowledge; they were social persons. Through such research, Imanishi's influence rippled across many fields in Japan, including evolutionary biology and anthropology. Yet in each of these fields, his legacy is also problematic-and this is why his name was never spoken. The not-speaking of Imanishi's name was also key to the conference's success. When we asked, biologists explained that Imanishi was out of date and his methods parochial; their goal now was to advance by adopting international scientific standards. For anthropologists, the association between Imanishi and the Kyoto school of philosophy was significant: the Kyoto school of the early twentieth century, in its own "ontological turn," sought to craft explicitly "Japanese" modes of science and thought that distinguished themselves from those of the "West." Much of this work, however, was implicated in the militaristic nationalism that sponsored Japan's actions in World War II. The fact that the only outspoken disciple of Imanishi at the conference was a retired professor was significant. In dialogue with foreign "ontological turn" scholars, some Japanese scholars are today willing to reexamine the Kyoto school legacy, but most are still spooked by the associations between essentialism and fascism that are also part of this story. Rather than pursuing "Japanese" modes of knowing and being, Japanese scholars and scientists work at the crossroads of legibility between Western approaches and everyday Japanese ways of doing things. It is in this situation that not speaking about Imanishi, yet continuing Imanishi's habits of creating knowledge, was an effective part of the conference.

At the heart of conference discussions was the term "disturbance," but no one tried to force a transdisciplinary definition. It carried multiple associations with non-equalibrium ecologies, social upheaval, and human-caused environmental damage. An ecologists spoke about the importance of human practices, such as coppicing, in maintaining the biodiversity of Japan's anthropogenic woodlands, while a historian focused on jointly social and environmental disruption of massive water transport projects in India and China. Such under-definition encouraged congenial cross-talk rather than language policing.

A paper by historian Anthony Reid, which asked how tectonic activity may have shaped Sumatra's political history, best captured the Zeitgeist of the conference. Combining geoscience and historical research, Reid encouraged scholars to reexamine their assumptions about Sumatra's past. A combination of new natural science data and a reexamination of historical records pointed to many more earthquakes and tsunamis in the preceding 800 years than historians had conventionally presumed. This longue durée geologic volatility, Reid proposed, was itself an important historical actor, contributing to Highland dominance, a lack of ports on Sumatra's West Coast prior to the Europeans, and patterns of Islamization.

Reid's paper exemplified the unusual elements of the Kyoto conference. First, field-based observation guided the conversation between natural scientists and humanists. Second, longue durée histories and world-systems interactions guided the conference organizers' notion of what should be observed. Third, a refusal to define a singular conference paradigm did important work. These approaches allowed two kinds of promise to percolate. Conversations across disciplines could begin with small tendrils, rather than being pre-evaluated by big theory. But this also meant that the innovations of the conference were quiet, unspoken ones, left to participants to process on their own. The AURA project, inspired by this practice, has tried to push further in finding theoretical purchase for such enactments of curiosity about multispecies worlds.

\section{Aarhus at Santa Cruz: Arts of Noticing}

Quick guide: figuration—symbiosis; conference genre-field reports; practice-noticing 
Octavia Butler's "Blood Child" imagines a planet on which human colonizers, rather than ruling the planet, have been incorporated into a part-parasitic and part-symbiotic relationship as hosts to the dominant native species' larvae. The story revolves around a young man's decision to bear the larval young of one of the host species, despite the inequality and violence of the relationship. The story refuses conventional wisdom about human mastery and freedom in order to explore what taking co-species dependence seriously might mean. (Butler 1995)

In May 2014, the authors-all members of Aarhus University Research on the Anthropocene (AURA), a cooperative project between the University of California and Aarhus Universityorganized their own Anthropocene conference in Santa Cruz. The work at the heart of AURA begins with cultural anthropologists and ecological and evolutionary biologists. Around that core, transdisciplinarity flourishes, and artists, historians, philosophers, geographers, creative writers, and earth scientists have been key participants. But the core matters: at the center of our program are reflections about what fieldwork can offer for watching intertwined human and natural histories.

AURA argues that anthropology in general—and ethnography in particular-has something important to offer to research on the Anthropocene, namely a reminder of the power of noticing, of careful field description. Field biologists and ethnographers share this passion for noticing things anew. The method of AURA has been to start with method; a plodding rubber-boots approach to research on the Anthropocene. We offer a "slow science" (Stengers 2011) of joint research, of common readings, methods workshops, and fieldwork in which we share varied forms of know-how, from indigenous readings of forests to more-than-human histories in lake sediments. One of our joint research sites is an abandoned mining landscape of acid lakes and shifting sands in which life has unexpectedly bounced back. Walking though this landscape of death and life generates research questions that exceed the conceptual categories and expertise of any one discipline. Human and natural histories are inextricable here and across many scales of space and time. We ask not just what humans have wrought in the Anthropocene but also, in the spirit of Octavia Butler's short story, how multispecies life, in all its painful contradictions, comes to occupy the ruins we have made (Tsing 2015). Appreciating this requires new forms of collaboration and noticing.

It was in this spirit that the Santa Cruz conference was entitled "Arts of Living on a Damaged Planet." The goal was to stimulate conversations in which scholars might be willing to be infected by other disciplines. The play of science fiction provided a lure. The conference opened with a keynote address by science fiction writer Ursula K. Le Guin. Le Guin began with a fictive-science lecture (on the exo-linguistics of plant languages) and then, more seriously, discussed the relations of poetry and science, which each offer figures with which to navigate worldly challenges. The spirit of this invitation to learn from different genres pervaded the days that followed, which included a presentation on the social worlds of ants, an explication of a cartoon (on human-dog-wolf relations), a review of human extermination of megafauna, and an artist's "phytoplankton confessional," in which viewers spoke to plankton, which reacted by lighting up.

The panels themselves staged cross-field conversations that aimed to showcase the transformative possibilities of dialogue. One paired bacteriologist Margaret McFall-Ngai and science and technology studies scholar Donna Haraway. Their exchange on stage reflected the many years they have spent engaging each other's work. McFall-Ngai's path-breaking research on the importance of Vibrio bacteria to the developmental processes of Hawaiian bobtailed squid and Haraway's philosophies of "becoming with" developed within shared conversations about the 
symbiotic nature of all life. Their work was made possible by their abilities to notice and take seriously each other's scholarship. At the conference, McFall-Ngai gestured to Haraway's work while speaking of the revolution in biology that has followed the insight that microorganisms inside the rest of us make life possible. Haraway followed this with an argument that we should study the Anthropocene as the Chthulucene to remind us that relations, not "humans," make worlds. Like McFall-Ngai's discussion of the essential roles gut bacteria play in human life, Haraway's talk similarly stressed the relational nature of "anthropos." Haraway used chtulu-a tentacular entity part Greek earth deity, part science fiction figure, and perhaps part bacteria-infected bobtailed squid-to evoke the multiplicity of more-than-human powers that exist everywhere, including within ostensibly human bodies. McFall-Ngai and Haraway enacted the very relationality of which they spoke. They demonstrated that allowing other disciplines to live within one's own gut is what makes lively scholarship possible. Together, their content and conversational practices offered key reminders for conference participants: one can no longer pretend that survival can be enacted by one species-or one discipline-alone.

The subsequent conference panels opened other windows for dialogue. Cultural anthropologists were attending to multiple forms of learning - not just indigenous cosmologies, for example, but cosmologies together with practical arts of living with other species. Deborah Bird Rose, for example, combined Australian aboriginal insights about multispecies life with environmental scientists' observations on the multispecies impacts of single-species extinctions. Natural scientists, in turn, were learning to accept the observation that they are cultural producers as a compliment, not an insult. Meanwhile, cultural anthropologists at the conference became more aware of the radical commitments of many natural scientists. As we create a politics for collaborative survival on earth, we will need to create a mosaic of learning practices that transcend conventional divisions between the hard and the soft sciences, between different species, and between indigenous and metropolitan cosmologies. All this requires longer-term collaboration than a conference can offer. Yet the conference showed a potential path.

Of the Anthropocene projects we have reviewed, then, ours shares practical, how-to, concerns with the Kyoto group. Like them, we hope to encourage field research that discards the impediments of nature-versus-culture distinctions in order to allow us to reimagine life within human disturbance, in all its challenges. At the same time, we are also engaged in reworking conceptual and political categories-as are the groups that convened in Berlin, Milwaukee, and Rio. As with the Milwaukee group, feminist understandings of inequality and power are at the heart of our political concerns in both knowing and changing the world. As with the Rio group, alliances with indigenous peoples instruct us in what we can do. As with HKW in Berlin, the fusion of art and science is at the forefront of our ideas for public intervention. It is in the intersection between our engagement with the practical work of learning the Anthropocene and its implications for thought, art, and politics that we achieve our distinctive focus. Watching landscapes in action, we aspire to influence multispecies imaginations of what is possible.

The conference, however, was filled with incongruities and tensions. Two European anthropologists who attended the conference commented on the almost-religious experience of being in Santa Cruz. The inclusion of a non-academic science-fiction audience and the almostmillennial appeals to a better world struck them as exotic and mystifying, even as they were caught up in the enthusiasm of it. Americans, they thought, were preparing for the end of the world. Meanwhile, the conference alternated between serving organic treats and driving participants around in gas-guzzling vans. Perhaps this last is the most wrenching feature of the new Anthropocene imaginaries: however visionary, they are coupled with non-sustainable material practices of urban life, scholarly and otherwise. 


\section{Thought Experiments for the Anthropocene}

Every field carries promises and contradictions, but this feature of science and scholarship is particularly evident when a field is being born. Our reading of these five conferences allows us to consider the predicaments and haunted intentions that scholars are just now assembling around the term Anthropocene. In this section, we take stock of our readings to offer the insights of comparison.

Consider first the figurations, genres, and practices we found associated with the developing scholarship encouraged by each of the five conferences. The figurations we gleaned from each event are worth repeating as a list: transdisciplinarity (Berlin), contamination (Milwaukee), indigenous voice (Rio), disturbance (Kyoto), symbiosis (Santa Cruz). Each of these configures a particular way of "doing" the Anthropocene. Each configuration also carries risks and constituent contradictions. The HKW conference in Berlin worked hard to gather scholars and artists in order to find a new transdisciplinary space, a space achieved through play; yet such an exercise necessarily hazards the possibility that transdisciplinary will turn out to be the more mundane and conventional interdisciplinary. When scientists and humanists cannot understand each others' genres for play, we retreat into segregation, and every attempt to find a new space is haunted by this chance. The other configurations are no different in resting on such contradictions. The Milwaukee conference showed scholars the promise of thinking with contamination. Yet by stressing "everyday politics," it risked using forms of critique illegible to the powers to whom it sought to speak back. When the Rio conference raised the promise of the indigenous as an intervention into modern business as usual, the dilemma of who speaks for "the indigenous" was necessarily dragged along. At Kyoto, the legitimacy of "science" required conventional international forms, thus silencing the very interventions conference collaborations made possible through Japanese legacies. In Santa Cruz, advocacy for symbiosis required forms of "slowness" that could not be fulfilled in conference time, thus returning to the festival form, even in its refusal. Such hauntings are the stuff of every lively field, and it does not take away from the pleasures and promises of each of these configurations that they are haunted. Rather, figures and their constitutive hauntings help us see how contests form in the making of fields.

Genres, however, do slightly different work. They help us see future possibilities, rather than the development of tensions and debates. The genres we identified do not attempt to bound fields; instead, they show us ways to make new processes of field formation happen. When we consider the big question of the Anthropocene field-can scientists and humanists work together on urgent issues? - genres matter. They give traction to attempts to create new assemblies of advocates, experts, and artists. This is a way of reading the genres we identified: the carnival (Berlin); the everyday uncanny (Milwaukee); multiple perspectives (Rio); description (Kyoto); and field reports (Santa Cruz). In Berlin, it was the pleasure of a carnivalesque assembly of scholars and artists that showed how new groups might form. In Milwaukee, it was common immersion in experience-but experience variously queered by uncanny histories. In Rio, it was hope for mobilizing a new, more inclusive public, through listening to more varied perspectives. In Kyoto, it was play with description. In Santa Cruz, it was the pleasures of field reports, as these brought together humanists and scientists in arts of noticing. Each of these genres made new groupings possible for a science of the Anthropocene-but not the same groupings.

The practices we identified as enlivening each conference are also field-making exercises as they model how new scholarship might arise. Even more than genres, they need not contradict each other, and individual scholars can engage in many of these practices simultaneously. Yet they matter in field construction by making the imagination concrete. Practices at conferences cultivate skills for scholarship. At the conferences we review, we paid special attention to net- 
working (Berlin), deconstruction (Milwaukee), philosophy-fiction (Rio), excursions (Kyoto), and noticing (Santa Cruz). Networking creates a crowd of interested scholars from many fields. Another way to gather is to offer a model for future potential ways to meet; such practices also offer techniques for scholarly work in the Anthropocene. Organizers can use practices to create something new that might inspire others, whether trying out new kinds of voice or drawing attention to unnoticed common ground. HKW helped to build a field right there; the other conferences hoped that methods spreading from their conferences would do the job of field building. In each case, these methods are transformed by the project of thinking the Anthropocene; thus, for example, "noticing" brings biologists and anthropologists together to tackle urgent questions of collaborative survival.

What do these conferences teach us about the field of Anthropocene studies? First, it is clear that the Anthropocene, as a concept, will remain contested for some time to come. Second, among these contests, some issues are clear. Moving beyond the divide between the natural sciences and the humanities will not be easy. Hegemonies of knowledge are not easily surpassed. The practice of working up and down established knowledge hierarchies is fraught with problems.

Yet, despite such problems, there is extraordinary promise in this emerging field, which has sparked imaginations in so many different disciplines. Several striking features of the conjuncture make this an unusual opportunity. In contrast to earlier forays across the boundary between humanists and natural scientists, in which low-ranked humanists approached high-ranked scientists, the invitation here is offered by the scientists. Even more strangely, from the perspective of humanists, it is the scientists who are now raising the urgent political questions. Humanists in the twentieth century imagined themselves as politically engaged, in opposition to the supposed neutrality of the scientists. Now, however, scientists have opened radical political questions that promise to transform humanists' notions of politics. Indeed, for both humanists and natural scientists, the Anthropocene offers opportunities to rethink very basic scholarly habits and practices-and this, along with the urgency of the problems the term raises-is its great appeal.

In watching and participating in field building, science fiction can help. If we imagine ourselves building fantastic "worlds" as a way to reimagine current predicaments, we are offered schematic insights into our process. In this article, we have reviewed conferences by turning them into diagrammatic sketches of world building. In such thought experiments, we follow contrasts and internal contradictions. Our tools-figuration, genre, and practices-show us ways of reading conferences as fields coming into being.

The ability of the term Anthropocene to recruit so many scholars into new and exciting forms of curiosity and collaboration concerning the emergent present is a good reason to tarry with the Anthropocene. Despite its conceptual and political problems, we might, in Donna Haraway's phrase, "stay with the trouble" of the Anthropocene (2010). This is worthwhile because the many science fiction worlds that the Anthropocene is conjuring are replete with magic: thinking politics after the nature-culture divide; genuine kinds of transdisciplinarity; novel ways of imagining what it is to be "human," and the hope of survival in a world with other species. Rather than recapitulating pre-established epistemologies and ontologies, conferences stir up a witch's brew of ways of being, and the magic of the brew-organizers hope-brings something new into the world. The Anthropocene is a field still in ferment.

\section{ACKNOWLEDGEMENTS}

The authors would like to thank Thiago Cardoso for his ethnographic and analytical contributions to the section on "The Thousand Names of Gaia." We would also like to thank the ARES 
editors and four anonymous reviewers for their insightful and productive comments, which helped us to bring out our arguments.

HEATHER ANNE SWANSON, NILS BUBANDT, and ANNA TSING are core members of the Aarhus University Research in the Anthropocene program (AURA; for more, see: anthropocene. au.dk). With Elaine Gan, they are editors of the forthcoming Arts of Living on a Damaged Planet: Stories from the Anthropocene and curators of More Than Human: AURA Working Papers. Among their current and forthcoming books are Caught in Comparisons: Japanese Salmon in an Uneven World; The Empty Seashell: Witchcraft and Doubt on an Indonesian Island; and The Mushroom at the End of the World: On the Possibility of Life in Capitalist Ruins.

\section{NOTES}

1. The Anthropocene refers to a recently proposed geologic epoch for our present moment. A term coined by chemist Paul Crutzen in 2000, Anthropocene is now used by scholars, artists, and journalists to signal that we have entered an epoch in which human disturbance has become the most significant geologic force. The International Commission on Stratigraphy has convened an Anthropocene Working Group to consider the word (Subcommission on Quaternary Stratigraphy 2014). The committee cites a range of changes that they think call for a new temporal unit: changes in erosion and sediment transport due to colonization, agriculture, urbanization and global warming; changes in the chemical composition of the atmosphere, oceans and soils, with perturbations of carbon, nitrogen, phosphorus cycles; and alterations of the biosphere as a result of habitat loss, predation, species invasions, and ocean acidification.

2. For a few examples, see the programs of the Association of American Geographers 2014 Annual Meeting, the American Anthropological Association 2013 Annual Meeting, the 2014 Modern Language Association Annual Meeting, and the 2013 Annual Meeting of the European Association of Social Anthropologists.

3. http://anthropocene.au.dk

4. http://www.hkw.de/en/programm/projekte/2014/anthropozaen/anthropozaen_2013_2014.php

5. For general conference information, see http://c21uwm.com/anthropocene/ and http://www4.uwm .edu/c21/pages/events/conferences.html

For videos of conference keynotes, see http://c21uwm.com/anthropocene/conference-videos/

6. See http://c21uwm.com/anthropocene/

7. "Slurb," by artist Marina Zurkow, can be viewed at http://o-matic.com/play/slurb/index.html

8. Perhaps the need for this separation was not shared equally by all. Latour, a co-organizer of the colloquium, had previously used Gaia and Anthropocene almost synonymously (2013).

9. The conference was held 14-17 December 2009. For more information, see http://www.humano sphere.cseas.kyoto-u.ac.jp/en/article.php/2009092416475676.html.

\section{REFERENCES}

Adams, Douglas. [1980] 2009. The Restaurant at the End of the Universe. Basingstoke: Pan.

Butler, Octavia. 1995. "Blood Child." Pp. 1-32 in Blood Child and Other Stories. New York: Seven Stories Press.

Clarke, Arthur C. [1953] 2000. “The Nine Billion Names of God.” Pp. 417-422 in The Collected Stories. London: Orion. 
Cronon, William. 1995. “The Trouble with Wilderness; Or, Getting Back to the Wrong Nature." Pp. 69-90 in Uncommon Ground: Rethinking the Human Place in Nature, ed. W. Cronon. New York: Norton \& Co.

Danowski, Déborah, Eduardo Viveiros de Castro, and Bruno Latour. 2014. "Position Paper: The Thousand Names of Gaia: From the Anthropocene to the Age of the Earth, Rio de Janeiro, September 15-19, 2014." https://thethousandnamesofgaia.files.wordpress.com/2014/07/position-paper-ingl-para-site.pdf (accessed 26 September 2014).

Gallie, W. B. 1956. "Essentially Contested Concepts" Proceedings of the Aristotelian Society 56: 167-198. Haraway, Donna. 1988. "Situated Knowledges: The Science Question in Feminism and the Privilege of Partial Perspective." Feminist Studies 14, no. 3: 575-599.

Haraway, Donna. 1992. "The Promises of Monsters: Reproductive Politics for Inappropriate/d Others." Pp. 295-337 in Cultural Studies, ed. Larry Grossberg, Cary Nelson, and Paula Treichler. New York: Routledge.

Haraway, Donna. 2010. "When Species Meet: Staying with the Trouble." Environment and Planning D: Society and Space 28, no. 1: 53-55.

Haus der Kulturen der Welt. 2013a. “Anthropocenic Research Roundtable: January 11, 2013.” Transcript. Haus der Kulturen der Welt, Berlin.

Haus der Kulturen der Welt. 2013b. “The Anthropocene Project: An Opening. January 10-13, 2013.” Available online at: http://www.hkw.de/en/programm/projekte/2013/anthropozaen_eine_ eroeffnung/start_anthropozaen_eine_eroeffnung.php_(accessed 19 September 2014).

Imanishi, Kinji. [1941] 2002. A Japanese View of Nature: The World of Living Things. Translated by Pamela Asquith, Heita Kawakatsu, Shusuge Yagi, and Hiroyuki Takasaki. London: Routledge Curzon.

Ishikawa, Noboru. 2009. “Changing Nature of Nature: New Perspectives from Transdisciplinary Field Science." Japan Society Promotion of Science Global COE Program, In Search of Sustainable Humanosphere in Asia and Africa, Third International Conference. Kyoto University, 14-17 December 2009. http://www.humanosphere.cseas.kyoto-u.ac.jp/en/article.php/2009092416475676.html (accessed 26 September 2014).

Kuhn, Thomas. 1962. The Structure of Scientific Revolutions. Chicago: The University of Chicago Press. Latour, Bruno. 2013. "Facing Gaia. Six Lectures on the Political Theology of Nature. Being the Gifford Lectures on Natural Religion, Edinburgh, 18th-28th of February 2013." Website: http://www.brunolatour.fr/sites/default/files/downloads/GIFFORD-SIX-LECTURES_1.pdf (accessed 12 September 2014).

Latour, Bruno. 2014. “What Does Gaia Request of Us?” An Inquiry into Modes of Existence. 27 July 2014. Website: http://www.modesofexistence.org/what-does-gaia-request-of-us/ (accessed 20 September 2014).

Law, John. 2011. "What's Wrong with a One-World World." Heterogeneities. 25 September 2011. Available at: http://www.heterogeneities.net/publications/Law2011WhatsWrongWithAOneWorldWorld .pdf. (accessed 17 January 2015).

Le Guin, Ursula. 1969. The Left Hand of Darkness. New York: Ace Books.

Little, Paul. 1995. "Ritual, Power and Ethnography at the Rio Earth Summit" Critique of Anthropology 15(3): 265-288.

Mol, Annemarie. 2002. The Body Multiple: Ontology in Medical Practice. Durham: Duke University Press. Poncelet, E. C. 1990. "An Ethnographic Approach to the Conference: An Anthropological Perspective." Pp. 259-262 in Japanese/American Technological Innovation: The Influence of Cultural Differences on Japanese and American Innovation in Advanced Materials. Proceedings of the Symposium on Japanese/American Technological Innovation, ed. W. D. Kingery. Tucson: University of Arizona.

Nguyen, Huy Thiep. 2009. "Salt of the Jungle." Pp. 1-13 in Vietnam, ed. John Balaban and Nguyen Qui Duc, San Francisco: Whereabouts Press.

Schwägerl, Christian. 2014. The Anthropocene: A New Planet Shaped by Humans. Santa Fe: Synergetic Press. Somtow, Sukaritkul. 1986. "Fiddling for Water Buffaloes." Pp. 41-67 in Tales from the Planet Earth, ed. Frederik Pohl and Elizabeth Anne Hull. New York: Macmillan. 
Spivak, Gayatri Chakravorti. 1988. “Can the Subaltern Speak?” Pp. 271-313 in Marxism and the Interpretation of Culture, ed. C. Nelson and L. Grossberg. Urbana: University of Illinois Press.

Steffen, Will, Jacques Grinevald, Paul Crutzen, and John McNeill. 2011. “The Anthropocene: Conceptual and Historical Perspectives," Philosophical Transactions of the Royal Society A 369: 842-867.

Stengers, Isabelle. 2011. “'Another Science is Possible!': A Plea for Slow Science." http://threerottenpota toes.files.wordpress.com/2011/06/stengers2011_pleaslowscience.pdf (accessed 30 January 2015).

Strathern, Marilyn. 1991. Partial Connections. Savage, MD: Rowman and Littlefield.

Subcommission on Quaternary Stratigraphy. 2014. "Working Group on the 'Anthropocene.” International Commission on Stratigraphy. http://quaternary.stratigraphy.org/workinggroups/anthropocene/ (accessed 28 September 2014).

Tiptree, James, Jr. [1969] 2004. “The Last Flight of Dr. Ain.” Pp. 1-8, in Her Smoke Rose Up Forever. San Francisco: Tachyon Press.

Tsing, Anna. 2015. The Mushroom at the End of the World: On the Possibility of Life in Capitalist Ruins. Princeton: Princeton University Press.

Tyrrell, Toby. 2013. On Gaia:. A Critical Investigation of the Relationship between Life and Earth. Princeton: Princeton University Press.

Viveiros de Castro, Eduardo, Morten Axel Pedersen, and Martin Holbraad. 2014. "The Politics of Ontology: Anthropological Positions." In Fieldsights-Theorizing the Contemporary. Cultural Anthropology Online. 13 January. http://www.culanth.org/fieldsights/462-the-politics-of-ontologyanthropologicalpositions (accessed 24 September 2014).

Williams, Raymond. 1977. Marxism and Literature. Oxford: Oxford University Press.

Zalasiewicz, Jan. 2009. The Earth After Us: What Legacy Will Humans Leave in the Rocks? Oxford: Oxford University Press. 